DOI: $10.17148 /$ IARJSET.2021.8862

\title{
PROFESSIONAL QUALITY OF LIFE AND MENTALHEALTH AMONG CIVIL POLICE OFFICERS
}

\author{
Silpa Balagangadharan ${ }^{1}$ Anakha ${ }^{2}$ Akhil S. $S^{3}$ \\ ${ }^{1}$ Research Scholar, Department of Psychology, University of Kerala, Trivandrum, Kerala, India \\ ${ }^{2}$ Students' Counsellor, Kelappaji College of Agricultural Engineering and Technology, Thavanur, Kerala, \\ ${ }^{3}$ Former MPhil scholar, Sree Sankaracharya University of Sankrit, Kalady, Kerala, India
}

\begin{abstract}
This Study Examines Relationship between Professional Quality of Life and Mental health in Police Officers and the problem of the study is stated as "Professional Quality of Life and Mental health among Civil Police Officers. The sample size was determined by purposive sampling method $(n=175)$. In this study two standard questionnaires of Professional Quality of Life and Mental health profile were used. The reliability and validity of these two instruments were reported to be significant in different studies. The findings indicated that there is no significant difference among police officers on the basis of marital status, type of family, age, gender, educational qualification in Professional Quality of Life and Mental health. There is significant relationship among civil police officers in some domains of Professional Quality of Life and Mental health.
\end{abstract}

Keywords: Police, Mental health, Quality of life, Civil police officers, Professional quality of life

\section{INTRODUCTION}

The term police derive from Old French policie, which essentially means "civil organization." It derives from Late Latin poilita, which derives from Latin, which derives from Greek politeia, which derives from poiltes, which means "citizen," and polis, which means "city." As a result, 'police' was virtually synonymous with 'policy' at first. As a noun, 'police' refers to an administration that has been given the authority to actually enforce the law. Police, being a transitive word, means actively executing the law and, eventually, maintaining order among people (say a group), In addition, as a transitive word, 'police' might imply making (say, a military sector) seem clean. It is a judicial and executive system, for the government of a city, town, or district, for the preservation of rights, order, cleanliness, health, etc., and for the enforcement of the laws and prevention of crime; the administration of the laws and regulations of a city, incorporated town, or borough. The origins of early policing may be traced back to Anglo-Saxon England. The early Kings required total allegiance and obedience from all of their people. In exchange for this security, the Kings offered protection from foreign invaders or overzealous fords within the King's authority. A sort of internal police force emerged during the reign of King Alfred the Great. Alfred made it the responsibility of the different "thanes" or landowners throughout his realm to police his region, bring offenders to the King, and settle civil litigations. The people or "freemen" under cach thane became concerned that the thane mighty abuse or even exceed his power, and bunded together in a "rything which consisted of 10 families. This group would gather on a regular basis to talk about similar problems and mutual protection. However, the tything also acted as a "surety," or guarantee, that offenders within the family groups would be handed to the thane for disposal. They ensured that individuals who committed criminal crimes would be brought to justice. Furthermore, the tything frequently established neighborhood-watch patrols in which they kept a check on one other's homes to ensure that no harm occurred. The leader of this gang was dubbed a "tythingman." The following phase resulted from increasing shipping on the Thames River. Merchants were worried about the security of their ships and contents. They established a private police force to patrol the shoreline and ensure its safety and security. By 1800 , this group had been so effective in "cleaning up" the crime-infested waterfront that the City took it over. This, along with the fastincreasing industrial revolution and the rise of the middle class, which demanded an end to thieves, beggars, and prostitutes, prepared the way for the modern police force and Sir Robert Peel's work. The modern idea of police was 


\title{
International Advanced Research Journal in Science, Engineering and Technology
}

\author{
Vol. 8, Issue 8, August 2021
}

\section{DOI: 10.17148/IARJSET.2021.8862}

created in 1829, when Sir Robert Peel introduced legislation in the British Parliament outlining the conditions of a police force to operate inside the City of London. At the time, London was beset by criminal groups, and the safety of many residents was in doubt. Pick pocketing, gambling, and stealing, among numerous other crimes, were all widespread. The separation of policing and the courts was a key component of Peel's proposal. Peel and other law reformers of the time believed that the police should be responsible for one aspect of the law, up to and including prosecution, but the trial, conviction, and sentencing phases should be handled by another body, the judiciary. This notion has remained practically unaltered to this day.

The origins of police may be traced back to the feudal necessity of landowners to maintain a semblance of order on their estates through an unpaid and unruly rabble. The taint of its forefathers still has an impact on the morale of the lower ranks. The indigenous police system in India was remarkably similar to that of Saxon England: both were structured on the basis of land tenure, and just as the Thane in King Alfred's time was expected to deliver the criminal or fulfil the claim, so was the Thane in India. So, in India, the zamindar was obligated to capture any public order violators and to return stolen property or make good it's worth. There were a number of subordinate tenure-holders under the large zamindars, all of whom were required in their degree to perform police duties and to bear for the areas of their charges the responsibilities which rested on the zamindar for the entire estate; and, finally, there was, as a rule, the joint responsibility of the villagers, which could only be transferred if they succeeded in tracking the offender to the limits of another village. The headman enforced this community obligation, who was always aided by one or more village watchmen. These latter were the country's true executive police. Although there was usually just one watchman for the village, he was helped when necessary by all the male members of his family, the other village servants, and, in certain circumstances, the whole village population. His duties were to keep watch at night, find out all arrivals and departures, observe all strangers, and report all suspicions persons to the headman. He was expected to observe the character of every individual in the hamlet, and if a theft occurred inside the community's boundaries, it was his responsibility to track out the perpetrators. If he failed to retrieve the stolen goods, he was forced to make up the difference in value as far as his resources allowed, and the remaining was charged on the whole town. "The exaction of this indemnity" wrote Mountstuart Elphinstone, "is evidently unjust, since the village might neither be able to prevent the theft, nor to make up the loss, and it was only in particular cases that it was insisted on to its full extent; but some fine was generally levied, and neglect or connivance was punished by transferring the inani of the patel or watchman to his nearest relation, by fine, by imprisonment in irons, or by The Torture Commission of 1855 had brought to light great abuses in the working of the police in that presidency. One of the witnesses before the Commission stated that the police was a terror to well-disposed and peaceable people, none whatever to thieves and rogues and that if it was abolished into the saving of expense to Government would be great and property would be not a whit less secured than it then was. Another witness deposed that the police establishment had become the bane and pest of society, the terror of the community and the origin of half the misery that existed among the subjects of Government. The Commission advocated for the separation of revenue and police responsibilities, as well as the placement of police facilities under the authority of independent European officials who could devote their whole time and energy to the control of the force. The Madras Government agreed with these viewpoints and recommended the appointment of a Superintendent of Police for each district, adding that it would almost certainly be necessary to have two Superintendents in some of the larger districts in the future, an expectation that has undoubtedly been confirmed by subsequent experience. These proposals were accepted by the Court of Directors, and a Bill was drafted by Mr. J.D. Mayne to give effect to them. It had been the original intention of the Government of Lord Harris to deprive the Magistrate of all executive control over the police, but before the Bill was passed Sir Charles Trevelyan had become Governor of Madras, and it was decided that the Superintendent should be placed under the orders of the District. The Bill was amended as a result, and it became law as Act XXIV of 1859.

Kerala Police, in its current form, dates back to 1956, when the state was formed as part of the reorganization of states following India's independence in 1947. In the pre-independence era, the region consisted of the princely states of Travancore and Cochin, and the Malabar region that came under the erstwhile province of Madras. Although the princely states did have their traditional forms of policing all along, the semblance of a modern police force was created in the late 19th century under the British rule. Oliver H. Bensley became the first Superintendent of Police for the state of Travancore in 1881. As the organization grew, Khan Bahadur Sayyid Abdul Karim Suhrawardy became the first Inspector General of Police of Travancore in 1938. The state of Cochin got its first IGP in 1942. 


\title{
International Advanced Research Journal in Science, Engineering and Technology
}

\author{
Vol. 8, Issue 8, August 2021
}

\section{DOI: 10.17148/IARJSET.2021.8862}

Policing is a professional job that empowers law and order in our society. It's a job that requires both physical and mental energy. These people are responsible for maintaining peace within our society, at all situations whether stressful or not. Policing has now become an integral part of the community. The study was conducted on police officers of CPO Rank, because they being the lowest rank among police officers, it is relevant to conduct a study on their Professional Quality of life. Professional quality of life is the quality one feels in relation to their work as a helper. Both the positive and negative aspects of doing your work influence your professional quality of life. People who work in helping professions may respond to individual, community, national, and even international crises. Helpers can be found in the health care professionals, social service workers, teachers, attorneys, police officers, fire fighters, clergy, transportation staff, disaster responders, and others. Understanding the positive and negative aspects of helping those who experience trauma and suffering can improve your ability to help them and your ability to keep your own balance. When conflict situations enhances, the stress level makes it impossible or unstable to do the responsibilities with full potential, affects the various aspects of mental health. Mental health refers to our cognitive and/or emotional wellbeing. It's all about how we think, feel and behave. Mental health, if someone has it can also mean an absence of a mental disorder. According to WHO mental health is a state of wellbeing in which the individual realizes his/her own abilities, can cope up with the normal stresses of life, can work productively and fruitfully and is able to contribute to his/her community. WHO stresses that mental health "is not just the absence of mental disorder".

\section{REVIEW OF LITERATURE}

Lauvrud.C. Nonstad K, and Palmstiemal carried out a research on Occurrence of post-traumatic stress symptoms and their relationship to professional quality of life (ProQoL) in nursing staff at a forensic psychiatric security unit: a crosssectional study. Violence is frequent towards nurses in forensic mental health hospitals. Implications of this high-risk environment have not been systematically explored. This paper explores occurrence of symptoms on post-traumatic stress and their relationship to professional quality of life. Self-report questionnaires assessing symptoms of post-traumatic stress and professional quality of life were distributed among psychiatric nurses in a high security forensic psychiatric unit with high frequency of violent behaviour. Relationships between post-traumatic stress symptoms, forensic nursing experience, type of ward and compassion satisfaction, burnout and compassion fatigue were explored. The prevalence of post-traumatic stress symptoms was low. Low scores were found on compassion satisfaction. Length of psychiatric nursing experience and low scores on compassion satisfaction were correlated to increased post-traumatic stress symptoms. The study concluded that although high violence frequency, low rate of post-traumatic stress symptoms and low compassion satisfaction scores was found in high staff/patient ratio and emotional distance.

Duracinsky M and et al put forward The Development of PROQOL-HIV: An International Instrument to Assess the Health-Related Quality of Life of Persons Living With HIV/AIDS Analysis revealed underlying themes: general health perception, social relationships, emotions, energy/fatigue, sleep, cognitive functioning, physical and daily activity, coping, future, symptoms, and treatment. Seven issues new to HIV-HRQL measurement were subsumed by these themes: infection fears, future concerns, satisfaction with care, self-esteem problems, sleep problems, work disruption, and treatment issues. HIV patients across 11 countries attributed a wide range of physical, mental, and social issues to their condition, many of which were not measured by existing HIV-HRQL instruments.

Coping has also a temporal aspect. One can cope before a stressful event takes place, while it is happening (e.g., during the progress of a disease), or afterwards. Bechr and McGrath (1996) distinguish five situations that create a particular temporal context: (a) Preventive coping: Long before the stressful event ocurs, or might occur, for example, a smoker might quit well in time to avoid the risk of lung cancer; (b)Anticipatory coping: when the event is anticipated soon; for example, someone might take a tranquillizer while waiting for surgery: (e) Dynamic coping: while it is ongoing; for example, diverting attention to reduce chronic pain; (d) Reactive coping: after it has happened; for example, changing one's life after losing a limb; and (e) Residual coping: long afterward, by contending with long-run effects, for example, controlling one's intrusive thoughts years after a traumatic accident has happened.

Five coping strategies were identified Klauer and Filipp (1993) that turned up as dimensions in a factor analysis: (a) Seeking social integration, (b) rumination, (e) threat minimization. (d) turning to religion, and (e) seeking information. These factors were established as subscales of a psychometric inventory that was used in the present study (see also Aymanns, Filipp. \&Klauer, 1995).

Mental health problems at early stage remain unrecognized and untreated. There is tendency to conceal even severe psychiatric problems due to stigma. It is proposed to develop models for mental health care in urban areas with focus on 


\title{
International Advanced Research Journal in Science, Engineering and Technology
}

\author{
Vol. 8, Issue 8, August 2021
}

\section{DOI: $10.17148 / I A R J S E T .2021 .8862$}

extension of mental health care to community level. WHO funded project on urban mental health problems and service needs has been initiated with many objectives. To begin with is to study the utilization pattern of existing mental health care facilities in geographically defined urban area, and assess strengths and weaknesses. In addition, to study the pattern of mental health problems through (a) Data available from mental health care facilities, (b) Qualitative descriptive studies on mental health problems in the community. Finally, is to identify and develop strategies for early identification of mental health problems and to suggest necessary intervention, including appropriate services.

Peter Huggard and Robyn Dixon. Health Care, Faculty of Medical and Health Sciences, University of Auckland, New Zealand, found that Compassion fatigue, also referred to as secondary traumatic stress, is increasingly being acknowledged as a possible consequence of working in any helping and caring profession. Previous research has focused on examining this construct in a variety of health professionals-social workers, counsellors, psychologists and nurses; however, little attention has been paid to this experience in doctors. This research examined the presence of compassion fatigue in doctors. A self-selected sample of 253 doctors, working in four locations in New Zealand and training in a variety of specialty disciplines, participated in this research by completing an anonymous questionnaire which included the ProQOL (Professional Quality of Life) instrument. This instrument measures compassion fatigue, burnout and compassion satisfaction. Results indicated that $17.1 \%$ of the sample appeared to be at risk for compassion fatigue as indicated by a high score on that subscale of the ProQOL, and $19.5 \%$ at risk of burnout. These results are similar to those reported in studies of other health professionals and suggest a need for caution on the part of clinicians and employers as to the potentially emotionally demanding aspects of patient care. This study has reported the level of compassion fatigue, burnout, and compassion satisfaction in a group of Resident doctors working across a wide range of medical specialties. These findings have implications for those involved in the mentorship and pastoral care of doctors, the doctors' employers, medical professional associations, and for the doctors themselves. Additionally, these results can be drawn upon by those involved in undergraduate medical education as an indication of the level of distress experienced by doctors in the workplace.

\section{HYPOTHESES TO BE TESTED}

1. There is significant difference among police officers on the basis of marital status in Professional quality of life and mental health among civil police officers.

2. There is significant difference among police officers on the basis of type of family in Professional quality of life and mental health among civil police officers.

3. There is significant difference among police officers on the basis of age in Professional quality of life and mental health among civil police officers.

4. There is significant difference among police officers on the basis of gender in Professional quality of life and mental health among civil police officers.

5. There is significant difference among police officers on the basis of educational qualification in Professional quality of life and mental health among civil police officers.

6. There is significant relationship in Professional quality of life and mental health among civil police officers.

\section{METHOD}

This study is descriptive- correlative. The statistical sample includes 175 civil police officers from various stations of Trivandrum district in Kerala. Subjects were selected as statistical sample through purposive sampling. Personal Data Schedule, Professional Quality of Life Scale, version 5 (B. Hudnall Stamm., 2009-2012) and Mental Health Profile (Sanandharaj and Rakhee 2003) were administered to them individually and were asked not to vomit any item. 175 samples were used for the analysis. The collected response was scored according to the scoring procedures provided for each tool. The data collected were analyzed using statistical techniques of $\mathrm{t}$ test and Pearson correlation method. 


\section{International Advanced Research Journal in Science, Engineering and Technology}

Vol. 8, Issue 8, August 2021

DOI: $10.17148 /$ IARJSET.2021.8862

\section{RESULTS}

The findings of the descriptive study are as shown in the following tables.

Table.1: Results of $\mathrm{t}$ test comparing marital status in professional quality of life and mental health $(\mathrm{N}=175)$

\begin{tabular}{|c|c|c|c|c|c|}
\hline \multirow{3}{*}{ Variables } & \multicolumn{4}{|c|}{ MARITAL STATUS } & \multirow{3}{*}{$\mathrm{t}$} \\
\hline & \multicolumn{2}{|c|}{ SINGLE(18) } & \multicolumn{2}{|c|}{ MARRIED(157) } & \\
\hline & M & SD & M & SD & \\
\hline ProQOLCS & 30.6111 & 7.09713 & 31.5732 & 6.07349 & .625 \\
\hline ProQOLB & 31.7222 & 5.88923 & 30.6624 & 5.68123 & .747 \\
\hline ProQOLCF & 30.1111 & 6.17289 & 31.8981 & 5.74700 & 1.240 \\
\hline MH-AS & 37.8889 & 6.61450 & 37.9618 & 7.44887 & 0.040 \\
\hline MH-I & 35.7222 & 7.92469 & 35.0000 & 7.353370 & .392 \\
\hline MH-A & 33.8889 & 6.53397 & 35.1465 & 6.27961 & .972 \\
\hline MH-PR & 34.3333 & 10.56632 & 35.7834 & 8.49458 & .161 \\
\hline MH-EM & 33.6111 & 7.17954 & 36.4968 & 6.68775 & .648 \\
\hline
\end{tabular}

The results given in table 1 shows the comparison between marital status and study variables. The t test scores compared the marital status, that is whether single or married, gives any difference in the Professional quality of life and mental health. The result obtained showed no significance in any of the scores, which can be due to the busy life schedule of police officers, or can be due to the difference between samples are unequal.

Table.2: Results of $\mathrm{t}$ test comparing type of family in professional quality of life and mental health.(N=175)

\begin{tabular}{|c|c|c|c|c|c|}
\hline \multirow{3}{*}{ Variables } & \multicolumn{4}{|c|}{ FAMILY TYPE } & \multirow{3}{*}{$\mathrm{t}$} \\
\hline & \multicolumn{2}{|c|}{ NUCLEAR(95) } & \multicolumn{2}{|c|}{ JOINT(80) } & \\
\hline & M & $\mathrm{SD}$ & M & SD & \\
\hline ProQOLCS & 31.1895 & 5.82419 & 31.8125 & 6.57978 & .625 \\
\hline ProQOLB & 30.6000 & 5.57044 & 30.9750 & 5.86769 & .747 \\
\hline ProQOLCF & 31.5053 & 5.57134 & 31.9625 & 6.08473 & 1.240 \\
\hline MH-AS & 38.5158 & 7.01801 & 37.2875 & 7.71681 & 0.040 \\
\hline MH-I & 34.3158 & 6.40190 & 35.9750 & 8.37412 & .392 \\
\hline MH-A & 35.9750 & 8.37412 & 34.7500 & 6.72359 & .972 \\
\hline MH-PR & 35.5368 & 9.16725 & 35.7500 & 8.18071 & .161 \\
\hline MH-EM & 35.8947 & 6.79404 & 36.5625 & 6.77830 & .648 \\
\hline
\end{tabular}

Results in table 2 shows the t-score of the comparison between the type of family, that is whether nuclear or joint and the study variables, Professional quality of life, stress tolerance and mental health. Here also no significance was found. It may be due to the fact that now a days there is no difference between nuclear and joint family, due to the busy life. The interaction between people has become really less because of the busy life style, where the family is nuclear or joint doesn't really matter. 


\section{International Advanced Research Journal in Science, Engineering and Technology}

Vol. 8, Issue 8, August 2021

DOI: $10.17148 /$ IARJSET.2021.8862

Table.3: Results of $\mathrm{t}$ test comparing gender in professional quality of life and mental health.(N=175)

\begin{tabular}{|c|c|c|c|c|c|}
\hline \multirow{2}{*}{ Variables } & \multicolumn{5}{|c|}{ GENDER } \\
\cline { 2 - 6 } & \multicolumn{2}{|c|}{ MALE(132) } & \multicolumn{2}{c|}{ FEMALE(43) } \\
\cline { 2 - 6 } & M & SD & M & SD & \\
\hline ProQOLCS & 30.9394 & 6.28916 & 33.1163 & 5.54295 & 2.027 \\
\hline ProQOLB & 30.9015 & 5.58058 & 30.3721 & 6.08285 & .528 \\
\hline ProQOLCF & 31.6894 & 5.65028 & 31.7907 & 6.30404 & .099 \\
\hline MH-AS & 37.8788 & 7.21748 & 38.1860 & 7.82626 & .237 \\
\hline MH-I & 35.0227 & 7.49602 & 35.2326 & 7.15421 & .161 \\
\hline MH-A & 34.9318 & 6.47743 & 35.2791 & 5.77897 & .313 \\
\hline MH-PR & 36.1439 & 9.12687 & 34.0698 & 7.13274 & 1.360 \\
\hline MH-EM & 36.7727 & 6.86466 & 34.5625 & 6.24615 & 1.975 \\
\hline
\end{tabular}

The above table results show the score of comparison between gender and study variables, which showed significance in two domains, the Professional quality of life-compassion satisfaction, which was found to be higher in females than males and mental health environmental mastery, which was found to be higher in males. The former was greater in females, for which we can say that females are satisfied with what they have regardless of any matters say for example, education, marital status etc., when it comes to environmental mastery, men are more capable than women to adjust with new surroundings and so on.

Table.4: Results of Duncan test comparing age in mental health - environmental mastery. $(\mathrm{N}=175)$

\begin{tabular}{|c|c|c|c|}
\hline \multirow{2}{*}{ AGE } & \multicolumn{2}{|c|}{$\mathrm{N}$} & \multicolumn{2}{c|}{ Subset for alpha= .05 } \\
\cline { 3 - 4 } & & 1 & 2 \\
\hline $25-35$ & 39 & 33.0000 & \\
\hline $35-45$ & 83 & & 36.4337 \\
\hline $45-55$ & & 53 & \\
\hline Sig. & & 1.000 & .169 \\
\hline
\end{tabular}

Comparing the Duncan's test results, we can interpret that the mental health environmental mastery is increasing with respect to age. The greater score was marked for those who falls between the age 45-55, the lowest was for 25-35.

Table.5: Results of Duncan test comparing education in professional quality of life- compassion satisfaction. $(\mathrm{N}=175)$

\begin{tabular}{|c|c|c|c|}
\hline \multirow{2}{*}{ Education } & \multirow{2}{*}{$\mathrm{N}$} & \multicolumn{2}{|c|}{ Subset for alpha=.05 } \\
\cline { 3 - 4 } & & 1 & 2 \\
\hline Degree and above & 52 & 29.8077 & \\
\hline
\end{tabular}


International Advanced Research Journal in Science, Engineering and Technology

Vol. 8, Issue 8, August 2021

DOI: $10.17148 /$ IARJSET.2021.8862

\begin{tabular}{|c|c|c|c|}
\hline SSLC & 57 & 31.4211 & 31.4211 \\
\hline Pre-degree & 66 & & 32.8333 \\
\hline Sig. & & .156 & .214 \\
\hline
\end{tabular}

In the above table it is found that those with medium level of education have high compassion satisfaction, and high level of education has the lowest level of compassion satisfaction. It can be due to the fact that they being this qualified got the lowest rank among police officers.

Table.6: Results of Duncan test comparing education in mental health- perception of reality(N=175)

\begin{tabular}{|c|c|c|c|}
\hline \multirow{2}{*}{ Education } & \multirow{2}{*}{$\mathrm{N}$} & \multicolumn{2}{|c|}{ Subset for alpha=.05 } \\
\hline & & 1 & 2 \\
\hline SSLC & 57 & 33.3509 & \\
\hline Degree and above & 52 & 35.7692 & 35.7692 \\
\hline Pre-degree & 66 & & 37.5000 \\
\hline Sig. & & .132 & .280 \\
\hline
\end{tabular}

The above table shows the result of Duncan's test comparing the educational qualification and mental health- perception of reality, where the highest score goes for those with medium level education and lowest is for those with low level of education.

Table.7: Results of correlation tests comparing the study variables

\begin{tabular}{|c|c|c|c|c|c|c|c|c|}
\hline & $\begin{array}{c}\text { ProQOL- } \\
\text { CS }\end{array}$ & $\begin{array}{c}\text { ProQOL- } \\
\text { B }\end{array}$ & $\begin{array}{c}\text { ProQOL- } \\
\text { CF }\end{array}$ & MH-AS & MH-I & MH-A & MH-PR & MH-EM \\
\hline $\begin{array}{l}\text { ProQOL- } \\
\text { CS }\end{array}$ & 1 & .058 & .079 & .117 & -.180 & .057 & .135 & .131 \\
\hline ProQOL-B & & 1 & .194 & .190 & .049 & -.153 & .008 & .038 \\
\hline $\begin{array}{c}\text { ProQOL- } \\
\text { CF }\end{array}$ & & & 1 & .192 & .131 & -.129 & .035 & -.002 \\
\hline MH-AS & & & & 1 & .118 & -.123 & .165 & -.023 \\
\hline MH-I & & & & & 1 & .071 & .135 & .149 \\
\hline MH-A & & & & & & 1 & .272 & .206 \\
\hline MH-PR & & & & & & & 1 & .222 \\
\hline MH-EM & & & & & & & & 1 \\
\hline
\end{tabular}

The above result shows the correlation between the various study variables and its domainsall the significant values are two tailed. Through the correlation test it is found that the Professional quality of life and mental health integration are significant at 0.05 level and the correlation score is 0.180 . The Professional quality of life burnout and Professional quality of life compassion fatigue are significant at 0.01 level. Its correlation score is 0.194 . The next two variables which are significant are Professional quality of life burnout and Mental health attitude towards self. Its correlation score was found to be 0.190 which is significant at 0.05 level. The Professional quality of life burnout and Mental health autonomy are significant at 0.05 level. Its correlation score is 0.153 . The Professional quality of life burnout and Mental health attitude towards self are significant at 0.05 level. Its correlation score is 0.192. Mental health attitude towards self and Mental 


\title{
International Advanced Research Journal in Science, Engineering and Technology
}

\author{
Vol. 8, Issue 8, August 2021
}

\section{DOI: 10.17148/IARJSET.2021.8862}

health perception of reality are significant at 0.05 level. Its correlation score is 0.165 . Mental health integration and Mental health environmental mastery are significant at 0.05 level. Its correlation score is 0.149 . Mental health autonomy and Mental health perception of reality are significant at 0.01 level. Its correlation score is 0.272 . Mental health autonomy and Mental health environmental mastery are significant at 0.01 level. Its correlation score is 0.206.Mental health perception of reality and Mental health environmental mastery are significant at 0.01 level. Its correlation score is 0.222 .

\section{SUMMARY AND CONCLUSIONS}

It was found that, even though not all but some of the domains of the study variable was found to be significant and also some shows significant relationship. It is found that there is significant relationship between age and Mental health environmental mastery. As age increases the Mental health environmental mastery also increases. It is found that there is significant relationship between Professional quality of life Compassion satisfaction and gender, that is compassion satisfaction is greater in females. It is found that there is significant relationship between Mental health environmental mastery and gender, that is environmental mastery is greater in males. It is found that there is significant relationship between educational qualification and Professional quality of life compassion satisfaction. The maximum compassion satisfaction was found to be in those having Pre-Degree level education and the minimum was for those having educational qualification degree and above.

It is found that there is significant relationship between educational qualification and Mental health perception of reality. The maximum perception of reality was found to be in those having Pre-Degree level education and the minimum was for those having educational qualification S.S.L.C. Significant relationship was found between the domains of the study variables. Positive correlation was found between burnout and compassion fatigue, burnout and attitude towards self, compassion fatigue and attitude towards self, attitude towards self and perception of reality, integration and environmental mastery, autonomy and perception of reality, autonomy and environmental mastery and perception of reality and environmental mastery. All these scores are positively correlated that when one increases the other also increases or when one decreases the other also decreases. Some are negatively correlated; they are compassion satisfaction and integration, burnout and autonomy. These values are negatively correlated such that when one increases the other decreases or vice versa.

The present study was on the Professional quality of life and mental health among civil police officers. The investigation was to find whether these variables are related to each other or factors such as age, type of family, gender, marital status or educational qualification influence these variables. The study gave results such as there is no significance for marital status and type of family to the study variables instead there is significance for factors such as age, gender and educational qualification on certain domains of the study variable such as compassion satisfaction, environmental mastery and perception of reality. Some of the domains of the study variables are also correlated with each other. The study was conducted to analyze various aspects such as professional quality of life and mental health among civil police officers and also the effect of factors such as marital, status, gender, type of family, educational qualification and age on these variables. The civil police officers were selected because that they are the lowest rank officers in a very stressful job.

\section{REFERENCES}

Akdere, M. (2006), "Improving quality of work life implications for human resources. The Business Review, Vol. 6 No. 1, pp. 173-177 Alderfer, C.P. (1972), Existence, Relatedness, and Growth Human Needs in Orgnizational Settings, Free Press, New York, NY.

Andrews, H. (1999), "Helping and Health," Advances: The Journal of Mind and Body, 7,pp. 25-34Schmitt, N. and Bedian, A.G. (1982), "A comparison of LISREL, and two-stage least squares analysis of a hypothesized life job satisfaction reciprocal relationship, Journal of Applied Psychology, Vol. 67 No. 6. pp. 806-817

Attewell, P. and Rule, J. (1984), "Computing and organizations what we know and what we don't know" Communications of the ACM, Vol. 27 No. 12, pp. 1184-1192..Bagozzi, R.P. and Yi, Y. (1988), "On the evaluation of structural equation models", Journal of the Academy of Marketing Science, Vol. 16 No. 1, pp. 74-95

Bagtasos, M.R. (2011), "Quality of work life: a review of literature", DLSU Business and Economic Review, Vol. 20 No. 2, pp. 1-8. Bartlett, M.S. (1950), "Tests of significance in factor analysis", British Journal of Statistical Psychology, Vol. 3, pp. 77-85.

Bowling, N., Watson, C., Bechr, T. and Rodriguez, S. (2004), "The quality of my work and

life", available at: www.document.com

Chan, K.W. and Wyatt, T.A. (2007), "Quality of work life: a study of employees in Shanghai,

China", Asia Pacific Business Review, Vol. 13 No. 4, pp. 501-517

Cheung, F.Y.L. and Tang, C.S.K. (2009), "Quality of work life as a mediator between emotional labor and work family interference", Journal of Business and Psychology, Vol. 24, pp. 245-255

Cronbach, LJ. (1951), "Coefficient alpha and the internal structure of tests", Psychometrika, Vol. 6 No. 3, pp. 297-334

Cunningham, J.B. and Eberle, T. (1990). "A guide to job enrichment and redesign, Personnel, Vol. 67. pp. 56-61. 


\section{International Advanced Research Journal in Science, Engineering and Technology}

Vol. 8, Issue 8, August 2021

\section{DOI: $10.17148 /$ IARJSET.2021.8862}

Daud, N. (2010), "Investigating the relationship between quality of work life and organizational commitment amongst employees in Malaysian firms". International Journal of Business and Management, Vol. 5 No. 10, pp. 75-82

Davis, L.E. (1983), "Design of new organizations", in Kolodny, H. and Beinum, H.V. (Eds), The Quality of Working Life and the 1980s, Praeger Publishers, New York, NY, pp. 65-86.

Duncan, G. (2003), "The quality of working life: is Scandinavia different?", European Sociological Review, Vol. 19. pp. 61-79

George, J.M. and Brief, A.P. (1990), "The economic instrumentality of work an examination of the moderating effects of financial requirements and sex on the pay-life satisfaction relationship", Journal of Vocational Behavior, Vol. 37 No. 3, pp. 357-368

Goldberger, L. And Breznitz, C., (1986). Hand Book of Stress. Theoretical and Clinical Aspects, New York: The McMilan Inc

Joiner, T. E. and Schmidt, N. B., (1995). Guest, R.H. (1979), "Quality of working life-learning from Tarrytown", Harvard Business Review, JulyAugust, pp. 76-77.

Gropel, P. and Kuhl, J. (2009), "Work-life balance and subjective well-being: the mediating role of need fulfillment", British Journal of Psychology, Vol. 100 No. 2, pp. 365-375

Hair, J.F., Anderson, R.E.. Tatham, R.L. and Black, W.C. (2005), Multivariate Data Analysis, Pearson Education, Delhi.

Hanefah, M.M., Zain, A.Y.M., Zain, R.M. and Hamzah, L. (2003), "Quality of work life andorganizational commitment among Malaysian public and government accountants", Malaysian Accounting Review, Vol. 2 No. 1

Havlovic, S.J. (1991), "Quality of work life and human resource outcomes". Industrial

Relations, Vol. 30 No. 3, pp. 469-479

Herzberg, F. (1966), Work and the Nature of Man, World Pub Co.

Heskett, J.L., Sasser, W.E. Jr and Schlesinger, A. (1997), The Service Profit Chain, Free Press, New York, NY.

Ivacevich, John M. and Matteson, Michael T.. (1983), "Stress: Can we Cope," Time,June 6, pp. 48.Cannon, W. B., (1935). "Stress and Strains of Homeostasis," American Foundation of Medical Sciences, 1989, pp. 1-14.

Islam, Z.M. and Siengthai, S. (2009), "Quality of work life and organizational performance: empirical evidence from Dhaka export processing zone", paper presented at the ILO Conference on Regulating for decent Work, International Labour Office, Geneva.

Jagannathan, L. and Akhila, P.R. (2009). "Predictors of quality of work life of sales force indirect selling organizations", The Indian Journal of Management Research, Vol. 8 No. 6, pp. 51-59

Kraut, R., Dumais, S. and Koch, S. (1989), "Computerisation, productivity and quality of work life" Communications of the ACM, Vol. 32 No. 2, pp. $220-238$ 